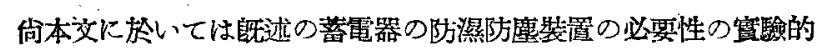
根握等に言及した。

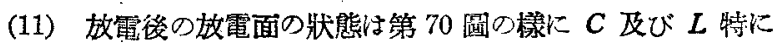
$L$ と密接な關係をなしアルミニゥム文はその合金の放電の均一性

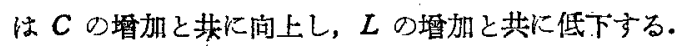

(12) a とC 及び $L$ との關係は主として可检元素線の種類 に閵你し母䌡元素線の種類や波長, 可檢元素線の波長及び可檢元 素( $\mathrm{Mg}$ 岂除く)には殆んど無閵係である。

(13) $a-L$ 并線 $(C$ - 定) は可检元素の種類及び $C$ に關係し $C$ が 10/10C の場合には可檢元素線が(I)の線の線組の曲線はあ る $L$ の值(多くす場合は $10 / 10 L$ ) て極大を示し可檢元素線が(II)

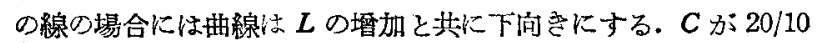
C の場合には $a-L$ 曲線は可检元㨞線の種類に拘らず何れも $a$ は 0/10〜1/10L で急に䐶加し $L$ が 1/10L より大きくなると此

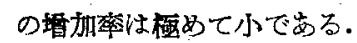

(14) $a-C$ 曲線 $(L$ 一定) は $L$, 可檢元素の種類に關係し可 撿元素線が(I)の線の場合には曲線出 $L$ の大小に上り方る $C$ の

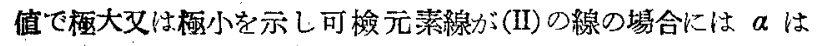

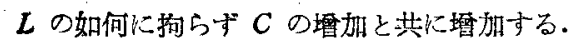

（15）绱本文に於いては $\mathrm{Mn}, \mathrm{Si}, \mathrm{Cu}, \mathrm{Fe}, \mathrm{Mg}$ 等の實用波展 城に於いて可能なる殆んぞ全部の線組の $\alpha$ に對する $C$ と $L の$ 摮動を詳細に解明し且之等の結果の縚用等に塄及した。

\section{弦光狀態と $\boldsymbol{C}$ 及び $\boldsymbol{L}$ との關係}

如上の $C$ 及び $L$ とスベクトル線の婊度， $\Delta S-T$ 曲線の型狀， 放電後の放電面の狀態, 放䉓による電電の溫度變化, 電流等との

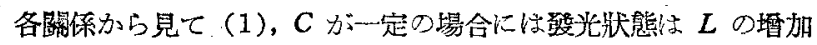

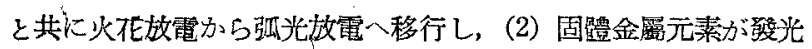

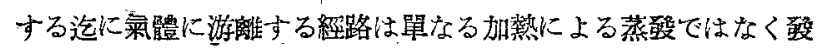

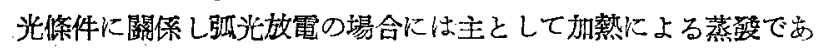
るが火花放電の場合には陰極飛沫作用に上る蒸破に上るものと考 察される.

\section{虺正なる $C$ と の粗合せ}

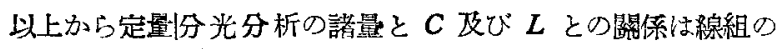
各線 (特に可檢元素線)の種類 (友び性質)に關係し且萬能的な $C$
と $L$ の組合せ梳ない樣である.從つて適正なる $C$ と $L$ の組合 せは使用せんとする線組，對象とする可检元素，憵用目的等に隹 じて選擇することが必要であることは多言を要しないであら5。 フルミニウム梨中の前記諸元素を別々に撮影せんとする場合又.は

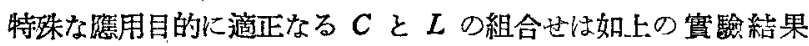
から容易に歸納し得るから記述を略するが蛞上の䁈驗結果の總括 からアルミニウム地金又はその合金中の既記各元美を出來る丈精 密且汛速に定量せんとする目的に對し最す適正と思はれる $C$ と $L$ の組合せを示せば第 31 表の通りである.

第 31 表 邀正なる $C$ と $L$ の积合せ

\begin{tabular}{|c|c|c|c|c|}
\hline 戟楜區分 & 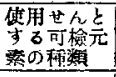 & 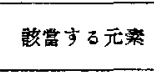 & \multicolumn{2}{|c|}{ 连正なる $C$ と $L$ の組合せ } \\
\hline \multirow{2}{*}{$\begin{array}{l}\text { 音通乃几ミ } \\
\text { 吊ム地金 } \\
\text { 刃はその合 } \\
\text { 金 }\end{array}$} & （I）の線 & $\begin{array}{l}\mathrm{Cu}, \mathrm{Si}, \mathrm{Mg} \\
(\mathrm{Mn}), \mathrm{Ni} \text { 等 }\end{array}$ & $10 / 10 C \leqq 10 / 10 L \leqq$ & \multirow{2}{*}{$\begin{array}{r}10 / 10 \sim 20 / 10 C \\
0 / 10 \sim 10 / 10 L\end{array}$} \\
\hline & (II) の縓 & $\begin{array}{l}\mathrm{Fe}, \mathrm{Mg}, \\
\mathrm{Mn}, \mathrm{Ti} \text { 等 }\end{array}$ & $20 / 10 C, \quad 1 / 10 L(\leqq)$ & \\
\hline \multirow{2}{*}{ 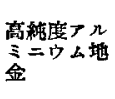 } & （I）の泉 & $\mathrm{Cu}, \mathrm{Si}, \mathrm{Mg}$ & $20 / 10 C, 10 / 10 L$ & \multirow{2}{*}{$\begin{array}{c}20 / 10 C \\
1 / 10 \sim 10 / 10 L\end{array}$} \\
\hline & (II) の線 & $\mathrm{Fe}, \mathrm{Mg}$ & $20 / 10 C, 1 / 10 L$ & \\
\hline
\end{tabular}

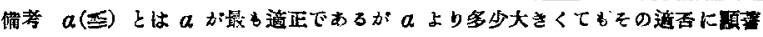

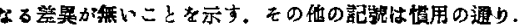

\section{(C と $L$ の組合せの項完)（續く）}

本報を終るに當り色々と御指導を賜り且本稿の各報を終始御校

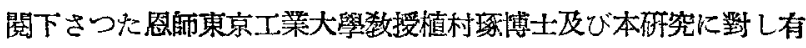
盆なる御忠言又は御薜援を睗つた大阪帝國 大拲教授渡瀨武男博

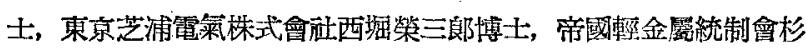
村盛一氏に對し謹んて深甚なる敬意と謝意を捧げる. 又種々御缏

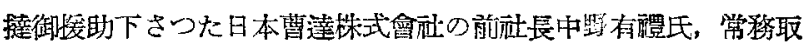
締役花田政害氏，前工場長服部誠造氏，工場長市川淔雄氏名始め

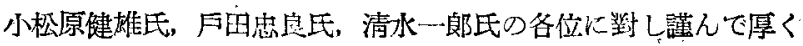
御䄚を申し上げる。(昭和 18 年 12 月 9 日受理)

\section{交献}

(23) 小田: 管化 11(昭 18)

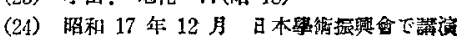

(25) 既出(小田, 篦化 11 (昭 18) 262)

\title{
オッファーマン法に依る弗素定量法に就いて
}

\section{杉本四朗石原勝}

（日本輕金屬株式會社淸水工場）

梗概、弗化物中の弗素定䔔法として最も普遍的なオッフアーマ

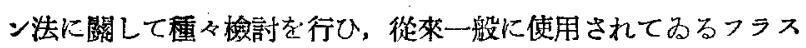

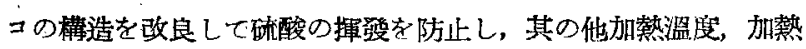

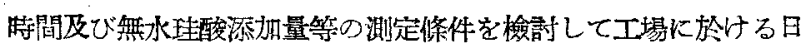
常分析に好適な方法を提案した.

\section{1. 綃}

弗化物中の弗素定最法としては色々な方法が提案されてるる が，工場们於ける日常分析として最も好適なのはオッフアーマン 法(1)、でらう。此の方法には次の如き特長がある。

1. 弗素を遖接定量し得ること.
2. 操作肪簡單て比較的讯速に行ひ得ること.

3. 白金器具及び特殊な薬品を要せぬこと.

一方を大同法には硫酸の影響を防止し得ない缺點があり，通常 結果が高く出ると言はれてるる．第 1 圖は才ッフアーマン法の定 量裝置を示す. 今試料を無水珠酸と混合して分解フラスコ(G)に

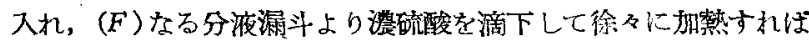
試料中の弗素は盡く $\mathrm{SiF}_{4}$ となつて挥臂するからとを $\left(K_{1}\right)\left(K_{2}\right) な$

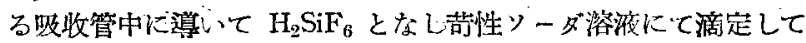
$F$ を求めるのである. 此の㻛合分解フラスコは $200^{\circ} \mathrm{C}$ 附近に加

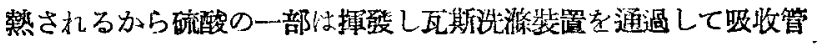




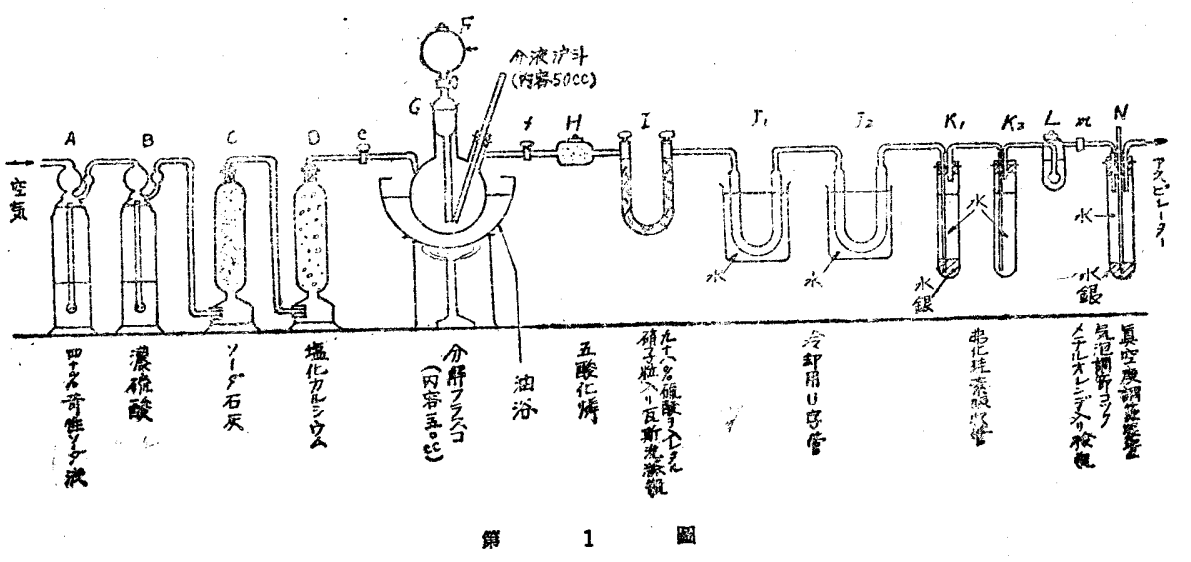

盡く孚鉢中に集め入れる。雨者を

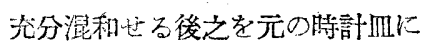
移し混和操作沖に附着せる水分を 除去する第に更に $110 \sim 120^{\circ} \mathrm{C}$ に て約 $30 \mathrm{~min}$ 間乾燥し然る後にデ シケーター中に放冷す. 定量装置 に空氣を通じつう漸絡及び磨り合 せ部分の妞密を充分點䌞せる後一 旦室氣を止め, 先の詞料を分解つ ラスコ $(G)$ 中に裝入す. 空氣を約 $15 \mathrm{~min}$ 間通じたる時コック $(m)$

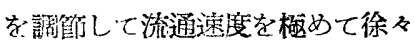
となし敏硫酸(備考 2)約 $10 \mathrm{cc}$ を

に侵入する無滴定の際に菂性ソーダを餘分に消定して定量值が高

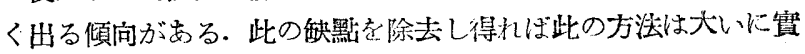

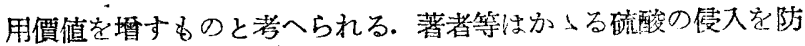
止する目的で分解フラスコを改良し，之を用ひて各種睄定條件を 檢討した結果從來の如く氣泡に依りフラスコ內を覔找することな

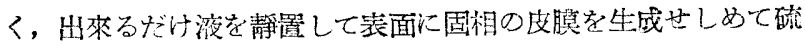
酸の揮䋿を防止し低溫で然も短時間分解することに依り正確な值 を得ることが出來た。

\section{2. 酼酸の理發防止}

今日一般に使用されてるる分解フラスコは第 2 圆 $\mathrm{a}$ ，b に示

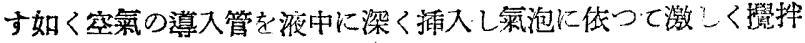

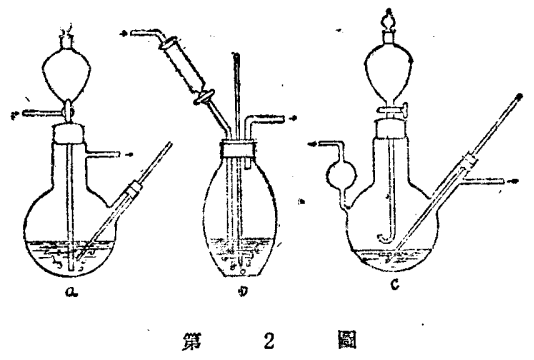

するやうになりてるる. 今試料を無水珪酸と鼬合してフラスョ肉

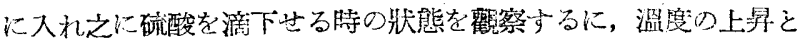
共に發生せる $\mathrm{SiF}_{4}$ 瓦斯は氣泡となって固相に附窟し之を液面に 浮場せしぬ暫時にして腹の表面は是等固相の皮膜に依つて一面に

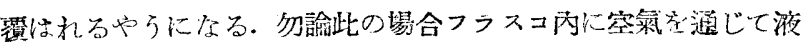

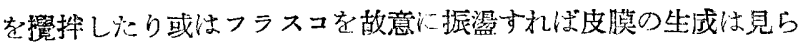

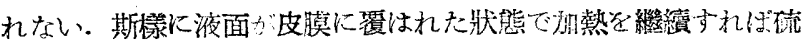

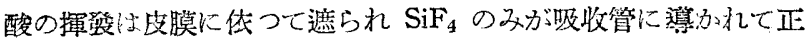

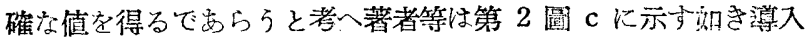
管のない分解フラスコ党用ひて賽驗を行つた。

鲃料 $\mathrm{Al}_{2} \mathrm{O}_{3}, \mathrm{Fe}_{2} \mathrm{O}_{3}, \mathrm{~S}, \mathrm{Ba}, \mathrm{Pb}, \mathrm{Zn}$ 等の不繦分を殆ど含有し ない純䖝石を選ず粉碎後 $10 \%$ 醋酸を用ひて $\mathrm{CaF}_{2}$ 以外の石灰

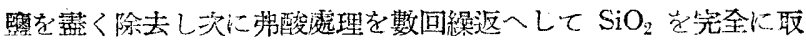
去つたるの老試料とした。此のすのを米國標淮局法 ${ }^{(2)}$ 儿传り分 析した所 $\mathrm{CaF}_{2}$ 99.95\% を得,他の成分は全然定量し得なかつた。 從つて殆ど純 $\mathrm{CaF}_{2}$ と見做して差芰へない。

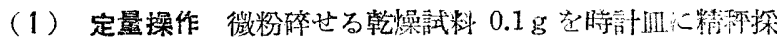

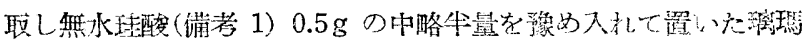

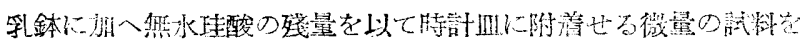

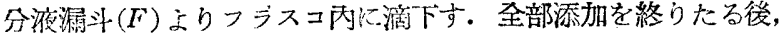
$1 \mathrm{sec}$ 間に 2〜3 氣泡の速度を以て空氣を通じつょバーナーに點 火し油浴の溫度を上䒜せしさ. 約 $30 \mathrm{~min}$ を要してフラスコ內の 液溫を $160 \sim 170^{\circ} \mathrm{C}$ に達せしめ引續き此の溫度に所定時間保持 ナ.㳄にバーナーを消しフラスコを充分振盪せる後更に約 $40 \mathrm{~min}$ 問空氣を通じたる後吸引を止め吸收管 $\left(K_{1}, K_{2}\right)$ の内容物を $600 \mathrm{cc}$ の圓錐ビーカー內に洗ひ入れ約 $70^{\circ} \mathrm{C} に$ 加熱しフェノールフタレ ソ數滴を加 $0.1 \mathrm{~N}$ 菏性》ーダ溶液にて僅に淡紅色を呈する迄

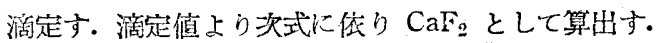

$$
{\mathrm{C} a F_{2}}_{2}=\frac{0.03904 \times N \times V \times 100}{S}
$$

$N$ : 萂性ソ - ダ溶㴼の規定, $V:$ 滴定 $\mathrm{cc}$ 數,

$S:$ 試料の量 $\mathrm{g}$

備考 1. 無水炼酸。水硝子を分解して珄酸を沈搌せしめ良く

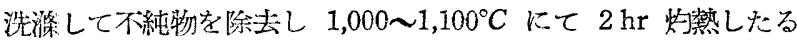

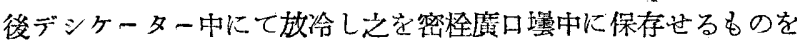
用与.

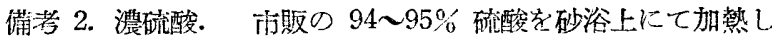

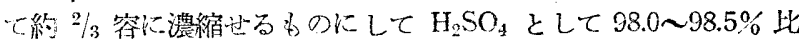
霍 1.841 のものを用ふ。

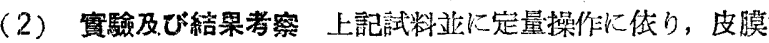

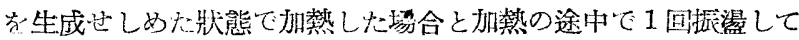
皮膜空破瓖した狀態で加篹した場合とを比較した。前者に於いて

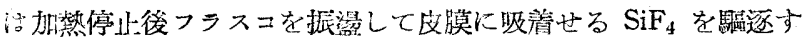
る如くなし，後者に於いては所定の加䓡溫度に到達してょり $1 \mathrm{hr}$

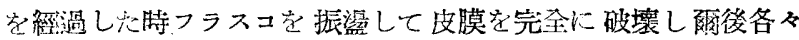

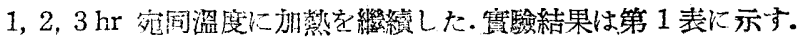

\begin{tabular}{|c|c|c|}
\hline \multirow{2}{*}{$\begin{array}{c}\text { LU熱時閒 } \\
(\mathrm{hr})\end{array}$} & \multicolumn{2}{|c|}{$\mathrm{CaF}_{2}(\%)$} \\
\hline & 皮茣が存在す万埸合 & 皮膛を破㙲した㙞合 \\
\hline 1 & 100.00 & - \\
\hline 2 & 100.00 & 100.23 \\
\hline 3 & 100.01 & 100.45 \\
\hline 4 & 100.14 & 100.58 \\
\hline
\end{tabular}

郎ち皮莫が存在するとさは各時間共上く一致した檤を得るが皮

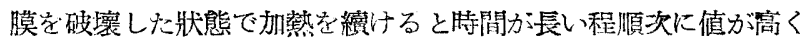

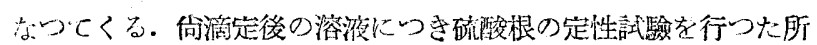

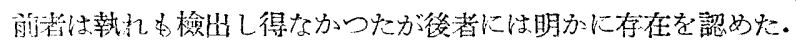

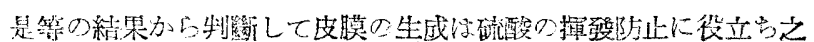




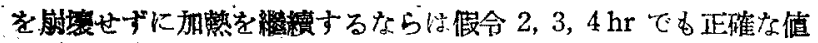
を與へるものと考へられる。

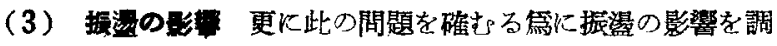
ベた. 前と同じ試料を用ひ所定の溫度に到澾してより $1 \mathrm{hr}$ 加熱

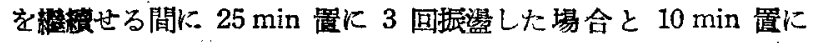
6 回振湯した場合と机熱中には振湯せずに停止後之を行つた場合 及び全然振湯しなかつた場合に就いて比較穓匳を行つた。夫等の 結果は第 2表に示す.

\begin{tabular}{|c|c|c|}
\hline - & $\mathrm{CaF}_{2}(\%)$ & $\mathrm{SO}_{4}^{-}$ \\
\hline 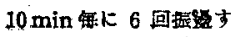 & 100.64 & 可成有 $b$ \\
\hline 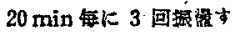 & 99.45 & 僅にわり \\
\hline 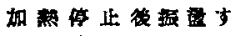 & 100.00 & 然 し \\
\hline 全然证 & 99.41 & 無 \\
\hline
\end{tabular}

是等の中 $20 \mathrm{~min}$ 每に 3 回振蕰した場合が却つて低い値を示

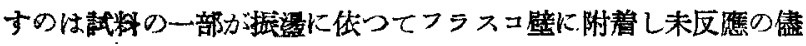

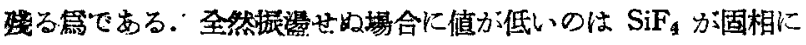

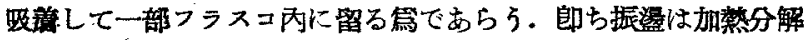

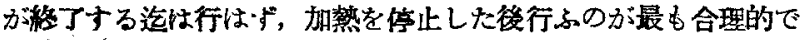
又正確な值を與へる。

\section{3. 加第 特 間}

オッフフーマン法に於ける加熱持間は通常 3〜4 hr と覞定され てるるが工場分析としては可及的速かなるを要するので加算㭙間

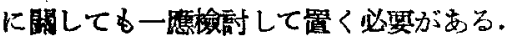

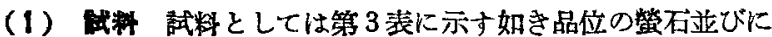

\begin{tabular}{|c|c|c|c|c|c|c|c|c|}
\hline 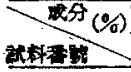 & $\mathrm{CaF}_{2}$ & $\mathrm{SiO}_{2}$ & $\mathrm{CaCO}_{3}$ & $\left|\begin{array}{c}\mathrm{Al}_{2} \mathrm{O}_{3}+ \\
\mathrm{Fe}_{2} \mathrm{O}_{3}\end{array}\right|$ & $\mathrm{s}$ & $\mathrm{Ba}$ & $\mathrm{Pb}$ & $\mathrm{zn}$ \\
\hline & 99.95 & - & - & - & - & - & - & - \\
\hline 2 & 97.08 & 1.83 & 0.49 & 0.49 & - & - & - & - \\
\hline 像 3 & 82.08 & 12.75 & 0.67 & 2.83 & - & - & - & - \\
\hline 4 & 40.95 & 43.66 & 2.40 & 9.04 & - & - & - & - \\
\hline 5 & 15.87 & $68.66^{-}$ & 2.71 & 10.41 & - & - & - & - \\
\hline 些分 $(\%)$ & 济 & 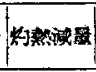 & Al & $\mathbf{F}$ & $\mathrm{Na}$ & $\mathrm{Fe}_{2} \mathrm{O}_{3}$ & so & $\mathrm{SiO}_{2}$ \\
\hline 6 & 0.83 & 3.99 & 17.59 & 54.91 & 26.75 & 0.04 & a.12 & 0.48 \\
\hline 水晶 & 0.27 & 1.38 & 14.22 & 52.96 & 29.76 & 0.67 & 1.35 & 0.62 \\
\hline 8 & 0.03 & 0.02 & 13.30 & 52.07 & 33.45 & 0.04 & 0.10 & 0.38 \\
\hline
\end{tabular}

米晶石計 8 種を用ひた．同表に示す螢石の分析值は標洦局法に依

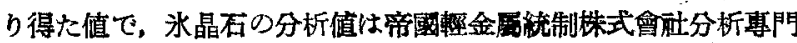
委員會並じに日本人造米昆石組合との合蓝に上り決定せられたる

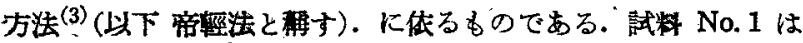
2. に於いて使用せるすのと同しで純 $\mathrm{CaF}_{9}, \mathrm{No} 6$ 及び 7 は某律

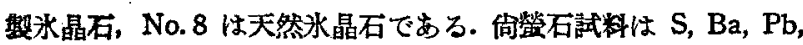
Znについても定量在行つたが何れる微量の学定量し得なかつた。

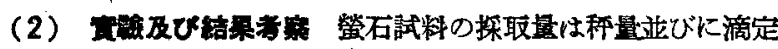
に传る誤差を定贯值に對して略一栚にならしめる偏に品位に應じ て通虽に定め， $\mathrm{CaF}_{2}$ として常に約 $0.1 \mathrm{~g}$ ある如くなした．水晶

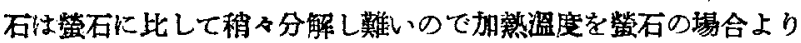

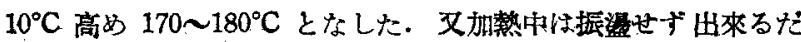

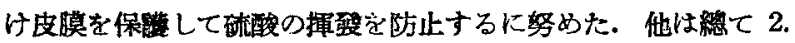

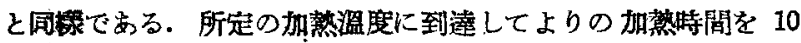
min より $4 \mathrm{hr}$ に至るまで硾る隹化せしめた時の結果を第 4 表，

\begin{tabular}{|c|c|c|c|c|c|c|c|c|}
\hline & \multicolumn{5}{|c|}{ 䠄 } & \multicolumn{2}{|c|}{ 永 晶 } & 不 \\
\hline 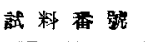 & 1 & 2 & 3 & 4 & 5 & 6 & 7 & 8 \\
\hline 陚料 $\mathbf{P}$ (g) & $|0.1000|$ & 0.1000 & 0.1000 & 0.2500 & 0.6000 & 0.1000 & 0.1000 & 0.1000 \\
\hline 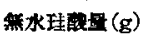 & $0 . \overline{8}$ & 0.5 & 0.5 & 0.3 & 0 & 0.5 & 0.5 & 0.5 \\
\hline 加等晴脚 $(\mathrm{m})$ & \multicolumn{5}{|c|}{$\mathrm{CaF}_{2}(\%)$} & \multicolumn{3}{|c|}{$\mathbf{F}(\%)$} \\
\hline 10 & 94.43 & 92.30 & 78.17 & 36.89 & 14.79 & 42.96 & 50.11 & 47.90 \\
\hline 20 & 95.88 & 94.21 . & 80.20 & 37.89 & 15.71 & 47.87 & 50.66 & 49.07 \\
\hline 30 & 98.03 & 95.65 & 82.09 & 39.12 & 15.99 & 51.59 & 51.16 & 50.11 \\
\hline $40^{\prime}$ & 100.01 & 97.03 & 82.09 & 41.11 & 16.00 & 53.49 & 51.99 & 51.58 \\
\hline 50 & 100.14 & 97.12 & 82.09 & 41.11 & 15.97 & 54.42 & 52.88 . & 52.07 \\
\hline 60 & 100.00 & 97.10 & .82 .13 & 41.11 & 15.97 & 54.91 & 52.96 & 52.03 \\
\hline 70 & 100.04 & 97.14 & 82.13 & 41.11 & 16.00 & 54.91 & 52.96 & 52.03 \\
\hline 80 & 100.02 & 97.09 & 82.10 & 41.11 & 16.00 & 54.91 & 52.96 & 52.03 \\
\hline 90 & 100.00 & 97.12 & 82.11 & 41.13 & 16.00 & 54.91 & 52.96 & $52.03^{\circ}$ \\
\hline 120 & 100.06 & -97.10 & 82.09 & 41.10 & 15.99 & 54.91 & 52.96 & 52.07 \\
\hline 180 & 100.09 & 97.13 & 82.15 & 41.11 & 16.02 & 54.91 & 52.96 & 52.07 \\
\hline 240 & 100.15 & 97.24 & 82.23 & 41.13 & 16.05 & 54.95 . & 92.96 & 52.07 \\
\hline 標準层法 & 99.95 & 97.08 & 82.08 & 40.95 & 15.87 & - & - & - \\
\hline
\end{tabular}

第 3 圖敢び第 4 圆に示す.

純 $\mathrm{CaF}_{2}$ と考へられる試 料 No.1の結果を見るに所 定の溫度に 到達してょり $40 \mathrm{~min}$ にして CaF 100 を

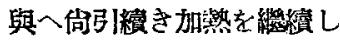
ても㱠ど變化がない，他の 4 箇の螢石試料も之と同じ

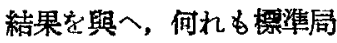
法に依る分析值とよく一致 してるる. 皮晶石の場合は 䖪石に比して分解困蜼のや らであるが, 50〜70 min で 曲線は水平となり是れ以上 加熱特閪を延長してb磨化 がない，是等の結果からタ て加熱特間注所定温度に到
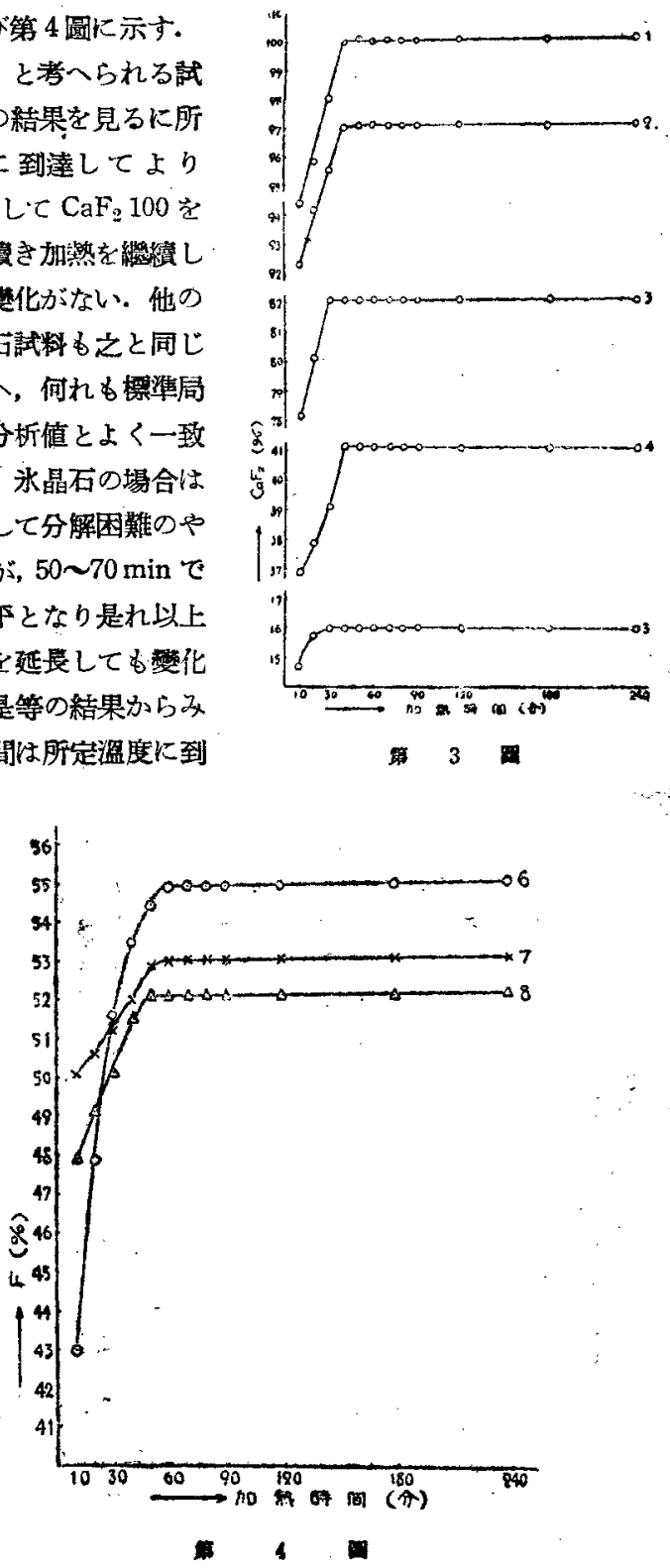


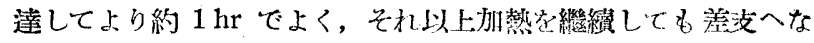
いが只時間の空費に遗ざないととが解る。

\section{4. 加 熱 溻 度}

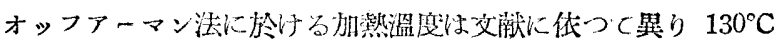
より $220^{\circ} \mathrm{C}$ の間て種々與へられてるるが昭和 16 年 9 月制定せら

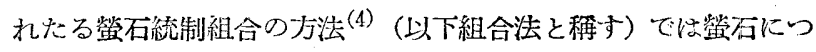
いて 200〜 $220^{\circ} \mathrm{C}$ と規定されて居り又帝輕法では泳晶石の場合に 約 $200^{\circ} \mathrm{C}$ と定められてるる. 而して溫度の高いのは硫酸の揮临を 促し然も生成皮膜を不安定ならしめるから高い結果を與へること

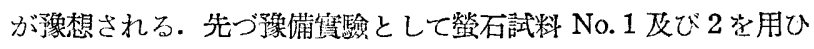
色々な溫度で分解を行つて定量值が如何に變化するかを檢傠して みたそそれと同㭙滴定液中へ侵入L.た硫酸を定性的に調べた。 是等の結果住第 5 表の如くである. 加熱溫度以外の條件は前の算

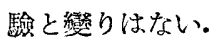

\begin{tabular}{|c|c|c|c|c|c|}
\hline \multirow{2}{*}{${ }^{\circ}$ 溫 $)^{\text {度 }}$} & \multicolumn{2}{|c|}{ 試 料 No. 1} & \multicolumn{2}{|c|}{ 敦 料 No. 2} & \multirow{2}{*}{$\mathrm{SO}_{4}^{--}$} \\
\hline & $\mathrm{CaF}_{3}(\%)$ & 渱 差 & $\mathrm{CaF}_{2}(\%)$ & 詔 差 & \\
\hline $145 \sim 150$ & 99.45 & -0.55 & 96.51 & -0.57 & 無 \\
\hline $160 \sim 170$ & 190.01 & +0.01 & 97.10 & +0.02 & 無 \\
\hline $175 \sim 185$ & 100.14 & +014 & 97.21 & +0.13 & 僅にあり \\
\hline $185 \sim 195$ & 100.23 & +0.23 & 97.30 & +0.22 & 僅に施! \\
\hline $195 \sim 205$ & 100.16 & +0.16 & 97.45 & +0.37 & 可的文 \\
\hline $205 \sim 215$ & 99.05 & -0.95 & 96.64 & -0.44 & 可俄あ! \\
\hline
\end{tabular}

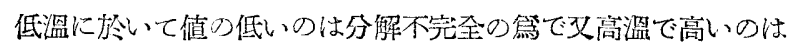
硫酸の影響に依るるのと考へられる. 事實高溫となる程フラスコ 內の友膜心不完全となり液面つ露出部分が大きくなつてくる.硫 酸の影響は高温となる程大であるから結果は㮌次に高くなつてよ い䈏であるが $200^{\circ} \mathrm{C}$ 以上になると却つて低い値を示してるるのは 此の溫度になると硫酸の熱分解が盛となり生成した水が $\mathrm{SiF}_{4}$ と 反應して $\mathrm{H}_{2} \mathrm{SiF}_{6}$ を生じフラスコの上部或は瓦斯の通路に筑第し て弗素の一部が吸收管に到達しない篇であら5と考へられる。柊 つ・溫度の餘りに高いのは不可であり篮石の場合は $160 \sim 170^{\circ} \mathrm{C}$ が適當で夫れより低くても高くても正確な值は得られない。

上記結果を確認する爲に水晶石試料 No. 6 及び 7 を用ひて同稳 の筫驗を行つた・此の堛合硫酸の影響を次の如き方法で定量的に

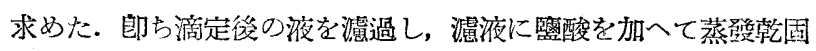
を數回絽返して $\mathrm{SiO}_{2}$ を不溶性ならしめると同特に軔素を分解掩 弡せしめ殘渣学温湯に溶解して㗬法に依り $\mathrm{BaSO}_{4}$ として它量し だ、丈之とは別に同じ加熱條件に於ける硫陵の空試驗を行つた。 結果は第 6 袁更び第 5 圆に示す.

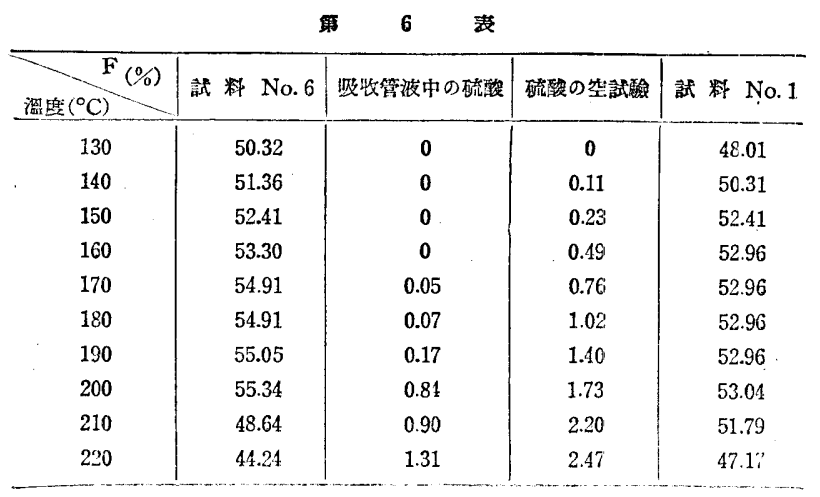

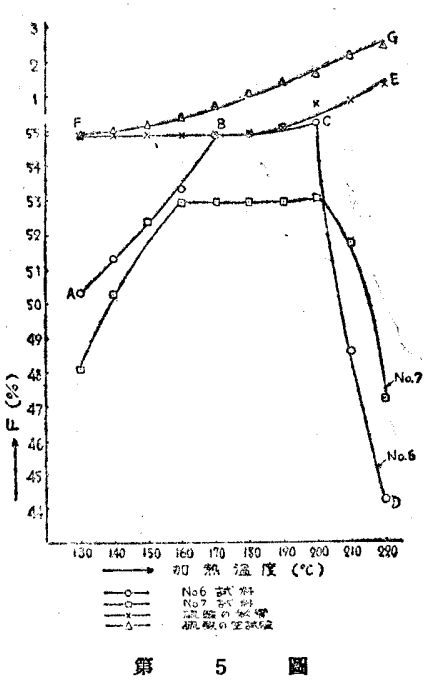

滴定液中の硫酸量を示寸曲線 $(F B E)$ と硫酸空試驗の曲線 $(F G)$ とは試料 No. 6 の弗蓄含有量 54.9 を原點として畫いた。曲線

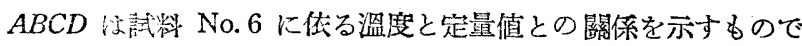
先の螢石の缶合と略同じ結果を與へてるる。 FBE は滴定液中の 硫酸量を $F \%$ に換算したときの曲線で, 若し硫酸の揮弲のみが 結果以影楊与るすのとすれば線は $A B E$ の如くなる等である。 然るた實際は $200^{\circ} \mathrm{C}$ 以上の值が却つて低くて曲線 $A B C D$ とな

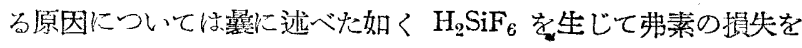
きたすからであらう：而して此の笉の負の誤差が硫酸の揮發に体 る正の誤差を遥に陵驾するから差引偩の誤差となりて曲線は著し く低下小るるのと考へられる. 試料 No. 7 の如くNo.6に比して 分解し易い(第 4 圖參照) ものは弗美の大半が揮散した後で硫酸の 熱分解が起るから $\mathrm{H}_{2} \mathrm{SiF}_{6}$ となつて殘る機會が少く從つて高溫の 誤差が No. 6 程著しくない，それ故に $210^{\circ} \mathrm{C}$ 乃至 $220^{\circ} \mathrm{C}$ の如き 高溫に加䓡与る場合も長時闑かっつて此の溫度に到達せしめれば 殘留弗熬が稳に少量となつた狀態で熱分解が起るから負の誤差は

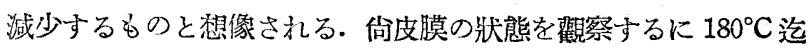
は破壤されずに居るがそれ以上になると、所々破れて液面か䈃出し $200^{\circ} \mathrm{C}$ 以上の高㴘となると皮膜は殆ど形成されない，是等の事實 と曲線 FBE とを比較教察すれぱ皮膜か硫酸の揮發浸入を防止す ることが一盧明膫に解るであらう，之を要するに加熱溫度の高い ことは皮膜の生成夌阻止すると同㭙に弗素の損失を招いて結果に

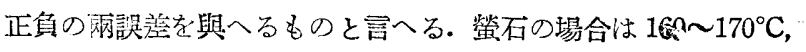
氷昆石ては $170 \sim 180^{\circ} \mathrm{C}$ が好週である.

\section{5. 然水珪酸添加量}

オッフフーマン法に用ひる無水理酸は HF とは容易に反應し 然も $\mathrm{SiF}_{4}$ を吸着しない性質のものがよいと言はれてるる．其の 第に帝輕法では水硝子を酸で分解して得たる純珪酸を $1,100^{\circ} \mathrm{C} に$ $1 \mathrm{hr}$ 炬䓡して作るやらに規定してるる. 然し都者等の經驗に依 れば必ずしも斯の樣な無水珠酸を必琶とせず市販の珪砂でも或は 海濱の砂を酸で精製して作つたものでも一问差支へない，無承珪 酸の添加量も亦償然定量值に影響を及ぼす等で多量の珄酸は却つ て篮石の分解を好げ又 $\mathrm{SiF}_{4}$ の吸收管への移行を好害するものと

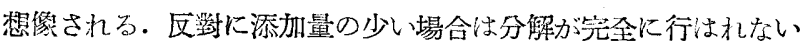

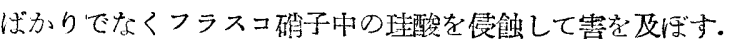

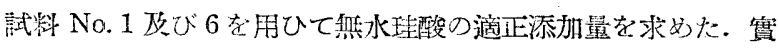

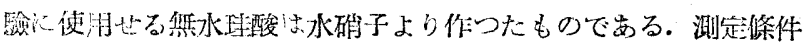




\begin{tabular}{|c|c|c|c|c|}
\hline \multirow{2}{*}{ 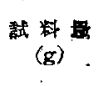 } & \multirow{2}{*}{ 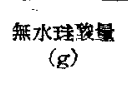 } & \multirow{2}{*}{$\begin{array}{c}\text { 䖝石镁料 No.1 } \\
\mathrm{CaF}_{2}(\%)\end{array}$} & \multicolumn{2}{|c|}{ 永晶不偝料 No. 6} \\
\hline & & & F $(\%)$ & 硫酸量(F\%) \\
\hline 0.1 & 0.1 & 9880 & 53.59 & 0.58 \\
\hline ' & 0.2 & 99.67 & 54.11 & 0.52 . \\
\hline$"$ & 0.3 & 100.60 & 54.51 & 043 \\
\hline$"$ & 0.4 & 100.00 & 54.93 & 0.37 \\
\hline " & 0.5 & 100.00 & 54.91 & 0 \\
\hline " & 0.6 & 100.00 & 54.93 & 0 \\
\hline$"$ & 0.7 & 97.73 & 54.83 & 0 \\
\hline$"$ & 0.8 & 97.47 & 54.51 & 0 \\
\hline " & 0.9 & 9927 & 54.17 & 0 \\
\hline
\end{tabular}

は從前の通り，結果は第 7 表に示す。

第 7 表の結果上り蛨石均合は $\mathrm{CaF}_{2} 0.1 \mathrm{~g}$ に對して 0.3〜0.6 g が適賞で從つて No. 5 の如く $\mathrm{SiO}_{2} 68.66 \%$ 当あるやうなるので

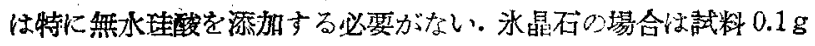

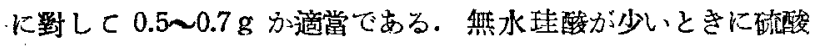
の影響が大であるのは皮膜が不完奎だからである。皮膜は添加量 の窗すに從つて完全で且つ强敂となるのは當然であらう。

\section{6. 比較 分 析}

今日オッファーマン法として展く行はれてるる最る代表的なる

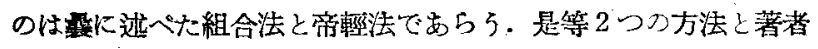
等力澵に定めた條件に低る方法(以下本法之記す) との定量條件D 主なるものを比較列舉すれば第 8 泰の如くである.

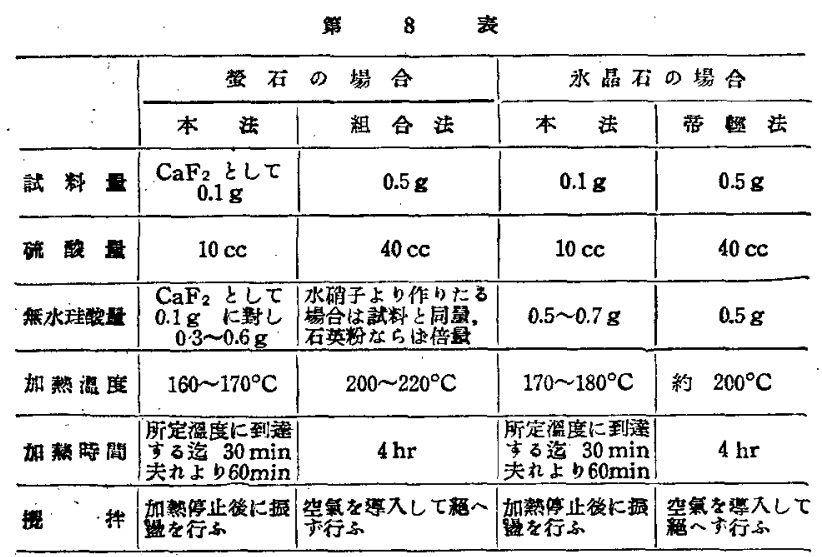

螢石の標㴶分析法として一般に認められてるるのは米國㯲準局 の制定せるものせあるが，今各産地の䖝石數種につき票準局法, 組合法, 本法の三者て定最せる值を比輘してみた。其の結果は第 9 表に示す. 是等の結果る見学に本法子組合法も米國標準局法に

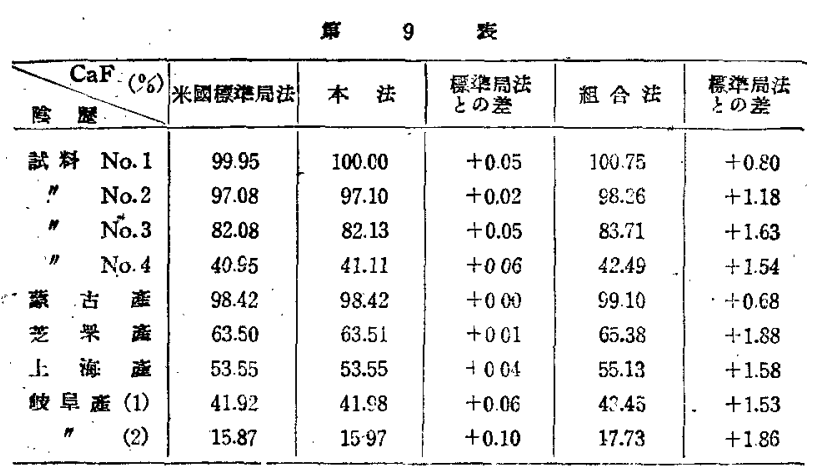

此して共に高い値を示してるるが本法は +0.1\% 以內てよく一婊 してるるに反し組合法は著しく高い值を示してるる.

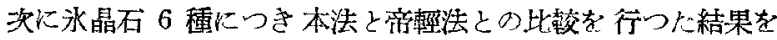
第 10 表に示与。表中硫酸ともるのは帝輕法に於ける滴定海中の 硫酸量齐試料量 $0.5 \mathrm{~g}$ としてF\%に換算したもので之に反して 本法に於いては執れも硫酸は存在しなかつたので表中には記載し てない. 帝輕法と本法との差は $\pm 0.5 \%$ 以队可成よく一致して るるが帝輕法では滴定液中に可成の硫酸が存在することから考入 て加熱溫度の高い笏の負の誤差と硫酸に依る正の誤差とが互に消 し合つて略正挽な䛧を與へてるるるのと考へられる。

\begin{tabular}{|c|c|c|c|c|}
\hline$F(\%)$ & 本 法 & 而敕法 & 兩法心望 & 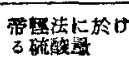 \\
\hline 試料 No.6 & 54.91 & 54.51 & -040 & 0.41 \\
\hline$" \quad$ No 7 & 52.96 & 53.36 & +0.40 & 0.46 \\
\hline " No. 8 & 52.07 & 52.53 & +0.46 & 0.43 \\
\hline $\mathrm{N}$ 践 整 品 & 54.05 & 54.36 & +0.31 & 0.45 \\
\hline $\mathrm{S}$ 凋繁品 & 52.33 & 52.20 & -0.13 & 0.45 \\
\hline N.N. 社型品 & 53.00 & 53.11 & +0.11 & 0.47 \\
\hline
\end{tabular}

\section{7. 總括}

オッフナーマン法に低り篮石並びに氷晶石申の弗素を定量する

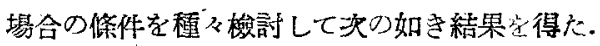

（1）篮石或は亦晶石を無水珪酸と混合して之に硫酸を滴下し て分解するとき登生せる $\mathrm{SiF}_{4}$ の氣泡か涸相を浮揚せしめて皮臊 を形成し，之か硅酸の揮發防止に役立つ.

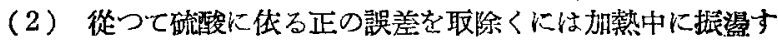

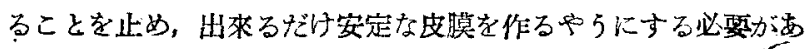
ว.

（3）其の罵には從來の如き室氣醇入管を有するフラスコは不 滴虽である.

（4）本筫驗には試料の探取量を螢石の場合は $\mathrm{CaF}_{2}$ として $0.1 \mathrm{~g}$ ，水晶石の場合も同樣に $0.1 \mathrm{~g}$ と定めたが工場分析には之で 充分である.試料が少いと吸收管中に生成する珄酸が少く從つC 舅入管が詰るやらな不都合を生じない，又满定に際して球酸の吸

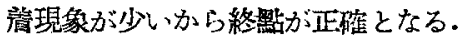

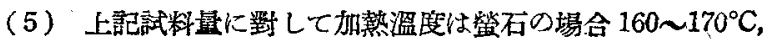

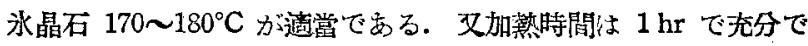
ある。

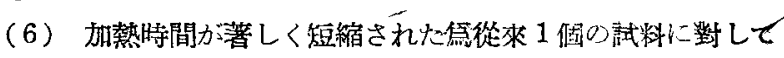
$8 \mathrm{hr}$ を要してるたものが $4 \mathrm{hr}$ で完了し得るやうになつた.

(7) 本法を算施して上り既に1万年になるが少しも支障なく 日常多數の試料を取接つて好結果を得てるる.

\section{(昭和 18 年 12 月 11 日受理)}

\section{文献}

(1) Offermann: Z. angew. Chem., 3(1890) 615 F. Seemann: Z. anal. Chem., $44(1905) 380$

(2) Lundell, Hoffman: Bureau of Standards Jour of Reseach; 2(1929) 671

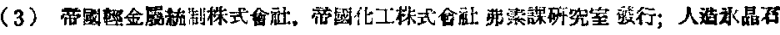
民张化アルミ分析法

(4) 整金犀時代: 118(昭 16)68

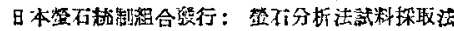

